\title{
MENINGKATKAN KETERAMPILAN BERBICARA TEKS ANEKDOT MELALUI MODEL PEMBELAJARAN ROLE PLAYING BERBASIS KONSTRUKTIVISME PADA PESERTA DIDIK KELAS X IPA-1 MAN SIDOARJO
}

\author{
Winawati \\ (Pendidikan Bahasa Indonesia, Fakultas Keguruan dan Ilmu Pendidikan, Universitas \\ PGRI Adi Buana Surabaya) \\ winawatiponti@gmail.com \\ Tri Indrayanti \\ (Pendidikan Bahasa Indonesia, Fakultas Keguruan dan Ilmu Pendidikan, Universitas \\ PGRI Adi Buana Surabaya) \\ Indrayant.tri@gmail.com
}

\begin{abstract}
This research aim to improve speaking skills by using role playing learning models based on constructivism in the tenth grade science-1 students of MAN Sidoarjo. The type of this research use collaborative action research. The theory used in this research is the theory of speaking skills from Arsjad and Mukti. The technique of analyzing data used quantitative and qualitative descriptive. The results showed that role playing learning models based on constructivism can improve students speaking skills by the teachers deliver the learning objectives, explain the role playing activities, divide the students into small groups, motivating the students to understand the material, give the students facilities to play a role, and guiding the students to discuss evaluate the role playing activities. The results showed that the learning process is increased. The improvement can be seen from the enthusiasm of the students and the students more orderly during the learning activities. Speaking skills improvement showed from the average acquisition value, before using the method increased about $49,34 \%$ to $75,68 \%$ in the first cycle and increased to $80,90 \%$ in the second cycle.
\end{abstract}

Keywords: speaking skills, role playing models, constructivism.

\section{PENDAHULUAN}

Keterampilan

berbicara merupakan salah satu komponen keterampilan berbahasa yang perlu dikuasai dan dikembangkan secara optimal. Hal ini dikarenakan keterampilan berbicara banyak digunakan untuk berkomunikasi sehari-hari dalam bentuk komunikasi tulisan maupun lisan. Salah satu tujuan dari berbicara sendiri yaitu untuk bertukar informasi. Selain itu komunikasi lisan juga mencakup penggunaan bahasa secara interaksional, yaitu fungsi-fungsi sosial dari berbicara.

Pada dasarnya dalam kehidupan secara umum tidak ada kriteria tentang standar berbicara yang baik, hal ini dikarenakan setiap orang memiliki cara dan gaya tersendiri dalam berbicara. Namun, di dalam pendidikan formal akan ditentukan kriteria berbicara yang baik untuk mengeneralisasikan penilaian dalam keterampilan tersebut.

Arsjad dan Mukti (dalam Saddhono, 2014:55) menyatakan ada dua faktor yang memengaruhi 
keterampilan berbicara dan sebagai acuan untuk penilaian berbicara yaitu faktor kebahasaan dan faktor nonkebahasaan yang menunjang keefektifan berbicara peserta didik. Faktor kebahasaan yang dimaksud yaitu ketepatan ucapan, pilihan kata atau diksi, ketepatan sasaran pembicaraan, penempatan tekanan nada, sendi, dan durasi yang sesuai. Dari segi nonkebahasaan faktorfaktor yang memengaruhi keterampilan berbicara antara lain adalah sikap yang wajar, tidak kaku, pandangan mata yang harus diarahkan kepada lawan bicara, gerak-gerik dan mimik yang tepat, kenyaringan suara, kelancaran, penalaran, dan yang tidak kalah penting adalah penguasaan topik yang akan dibicarakan.

Peristiwa penilaian keterampilan berbicara tersebut dapat dijumpai di lingkungan pendidikan. Proses belajar mengajar mata pelajaran Bahasa Indonesia khususnya keterampilan berbicara kelas X di MAN 1 Sidoarjo masih terdapat peserta didik yang kurang terampil dalam berbicara misalnya, peserta didik kurang menguasai intonasi dan pilihan kata yang diucapkan. Contohnya, ketika peserta didik diminta untuk menceritakan pengalaman lucu saat pertama masuk SMA, ada beberapa peserta didik yang bercerita dengan pengalaman lucunya tetapi ketika bercerita di depan peserta didik lain hasilnya kurang lucu, bahkan ada kejadian ketika peserta didik menceritakan pengalaman tetapi tidak mendapatkan perhatian dari peserta didik lain karena ketidaktepatan diksi atau pilihan kata yang diolah oleh peserta didik sehingga cerita menjadi tidak menarik. Kemudian, peserta didik juga diminta untuk menceritakan pengalaman lucunya ketika pertama masuk SMA, antara kalimat utama dengan kalimat selanjutnya tidak sesuai dan tidak berurutan.

Berdasarkan uraian tersebut maka penelitian ini membahas Meningkatkan Keterampilan Berbicara Teks Anekdot melalui Model Pembelajaran Role Playing Berbasis Konstruktivisme pada Peserta Didik Kelas X IPA-1 MAN Sidoarjo.

Rumusan masalah dalam penelitian ini adalah bagaimana penerapan model pembelajaran role playing dengan pendekatan pembelajaran konstruktivisme dalam proses pembelajaran teks anekdot untuk peserta didik kelas X IPA-1 MAN Sidoarjo dan apakah model pembelajaran role playing berbasis konstruktivisme dapat meningkatkan aktivitas pembelajaran dalam berbicara teks anekdot peserta didik kelas X IPA-1 MAN Sidoarjo?

Adapun tujuan dari penelitian ini adalah sebagai berikut.

1. Mendeskripsikan penerapan model pembelajaran role playing dengan pendekatan pembelajaran konstruktivisme dalam proses pembelajaran teks anekdot untuk peserta didik kelas X IPA-1 MAN Sidoarjo.

2. Mendeskripsikan peningkatkan keterampilan berbicara teks anekdot melalui model pembelajaran role playing berbasis konstruktivisme peserta didik kelas $\mathrm{X}$ IPA-1 MAN Sidoarjo?

\section{METODE PENELITIAN}

Penelitian ini dilaksanakan di Madrasah Aliyah Negeri Sidoarjo (MAN Sidoarjo) yang berlokasi di Jalan Stadion No. 2 Buduran, Kabupaten Sidoarjo. MAN Sidoarjo adalah sekolah yang menerapkan 2 
program pembelajaran yang menjadi program unggulan di madrasah ini, yaitu program jurusan yang terdiri dari jurusan IPA dan jurusan IPS, dan program unggulan yang meliputi asrama pondok pesantren atau ma'had, bimbingan baca tulis Alqur'an (BTQ), program pendidikan terapan bidak teknologi informasi dan komunikasi (PRODISTIK), dan club olimpiade bidang studi. Madrasah ini memiliki 38 kelas dan 2000 peserta didik, serta memunyai sarana dan prasarana yang lengkap sehingga memudahkan proses belajar mengajar.

Subjek penelitian ini adalah peserta didik kelas X IPA MAN Sidoarjo tahun ajaran 2018/2019 dengan jumlah kelas sebanyak 7 kelas. Dari 7 kelas tersebut untuk menentukan subjek penelitian maka dipilih melalui teknik simple random sampling. Dikatakan simple (sederhana) karena pengambilan anggota sampel dari populasi dilakukan secara random atau acak, cara demikian dilakukan karena anggota populasi dianggap homogen (Sugiyono, 2016:120).

Pengambilan sampel secara random dilakukan dengan pengundian oleh 7 kelas yang terdiri dari kelas $\mathrm{X}$ IPA-1, X IPA-2, X IPA-3, X IPA-4, $X$ IPA-5, $X$ IPA-6, dan X IPA-7. Setiap kelas mendapatkan nomor undian yang berupa huruf dan diundi sebanyak tiga kali. Karena teknik pengambilan sampel adalah random, maka setiap anggota populasi mempunyai peluang sama untuk dipilih menjadi anggota sampel. Dengan demikian cara pengambilannya bila nomor urut A telah diambil, maka perlu dikembalikan lagi, kalau tidak dikembalikan peluangnya menjadi tidak sama lagi.
Dari pengundian tersebut ditentukan bahwa subjek penelitian ini adalah peserta didik kelas X IPA-1 MAN Sidoarjo. Jumlah peserta didik 38 siswa yang terdiri atas 10 siswa laki-laki dan 28 siswa perempuan.

Penelitian ini menggunakan dua siklus, setiap siklus terdiri dari dua pertemuan dan dilaksanakan melalui tiga tahap yaitu kegiatan awal, kegiatan inti, dan kegiatan penutup. Masing-masing siklus dilaksanakan berdasarkan rencana pelaksanaan pembelajaran yang telah disusun oleh peneliti dan telah disetujui oleh guru mata pelajaran bahasa Indonesia.

Teknik pengumpulan data menggunakan teknik yang berupa tes dan teknik observasi. pada siklus 1 peserta didik mendemonstrasikan secara individu di depan kelas. Namun, setelah peneliti melakukan refleksi pada siklus 1 maka diketahui kelemahan peserta didik ketika berada di depan kelas yaitu kurangnya rasa percaya diri. oleh karena itu pendidik dan peneliti mengubah strategi pembelajaran menjadi strategi cooperative learning (belajar berkelompok). Pengubahan strategi belajar ini diterapkan pada siklus 2 dan untuk mengatasi rasa ketidakpercayaan diri peserta didik.

Tabel Perencanaan tes praktik berbicara

\begin{tabular}{|c|c|c|c|c|c|c|c|}
\hline \multicolumn{7}{|c|}{ 2- 20 Oktober 2018 } \\
Kelas X IPA-1 \\
\hline \multicolumn{7}{|c|}{ Siklus 1 } & \multicolumn{5}{c|}{ Siklus 2 } \\
\hline \multicolumn{3}{|c|}{ KD 4.5 } & \multicolumn{5}{c|}{ KD 4.6 } \\
\hline P & Mi & w & ju & P & Mi & W & kelo \\
r & ngg & kt & ml & r & ngg & kt & mpo \\
t & u & & ah & t & u & & k \\
& ke- & & & & ke- & & \\
\hline I & 1 & 55 & 10 & II & 2 & 55 & 3 \\
& & m & ora & & & m & \\
& & en & ng & & & en & \\
& & it & & & & it & \\
\hline II & 2 & 70 & 28 & II & 3 & 70 & 7 \\
\hline
\end{tabular}




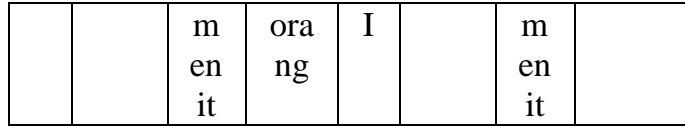

Keterangan:

KD : Kompetensi Dasar

Prt : Pertemuan

Wkt : Waktu

\section{HASIL PENELITIAN}

Untuk mengetahui tingkat keterampilan berbicara awal peserta didik peneliti melakukan tes pra tindakan. Tes pra tindakan keterampilan berbicara berupa tes praktik berbicara yang dilakukan secara individu. Dalam tes tersebut dua orang peserta didik diberikan teks bacaan yang sama dan diminta untuk membacakan teks tersebut dengan gayanya masing-masing. Sedangkan peserta didik lainnya diminta untuk mendengarkan dan mengomentari atau memberikan tanggapan menurut gagasannya sendiri secara tertulis kemudian diungkapkan secara lisan di depan kelas. Dari hasil tes pra tindakan dapat dianalisis persentase hasil tes keterampilan berbicara peserta didik kelas X IPA-1 sebagai berikut.

Tabel analisis persentase pra tindakan keterampilan berbicara

\begin{tabular}{|c|l|c|c|}
\hline No. & \multicolumn{1}{|c|}{$\begin{array}{c}\text { Aspek yang } \\
\text { diamati }\end{array}$} & Nilai & Persentase \\
\hline 1. & Nilai tertinggi & 90 & - \\
\hline 2. & Nilai terendah & 28 & - \\
\hline 3. & $\begin{array}{l}\text { Peserta didik yang } \\
\text { tuntas }\end{array}$ & 4 & $10,53 \%$ \\
\hline 4. & $\begin{array}{l}\text { Peserta didik yang } \\
\text { belum tuntas }\end{array}$ & 34 & $89,47 \%$ \\
\hline
\end{tabular}

Dari tabel penilaian pra tindakan keterampilan berbicara dapat diperoleh data bahwa rata-rata keterampilan berbicara peserta didik kelas X IPA-1 MAN Sidoarjo adalah $49,34 \%$. Nilai tersebut masih tergolong rendah jika mengacu pada nilai rerata mata pelajaran bahasa Indonesia yang telah ditentukan yaitu 79 karena masih berada di bawah nilai KKM. Data tersebut juga menunjukkan bahwa persentase kelululusan di kelas masih rendah.

Berdasarkan tes pra tindakan, jumlah peserta didik yang tuntas atau mendapatkan nilai lebih dari atau sama dengan 79 berjumlah 4 orang dari jumlah keseluruhan 38 peserta didik, jika dipersentasekan jumlah peserta didik yang tuntas masih $10,35 \%$. Jumlah peserta didik yang belum tuntas berjumlah 34 orang, jika dipersentasekan jumlah peserta didik yang belum tuntas $89,47 \%$.

Melalui hasil tes pra tindakan tersebut peneliti melakukan tindakan dalam yaitu penerapan model pembelajaran role playing berbasis konstruktivisme pada pembelajaran keterampilan berbicara dalam mata pelajaran bahasa Indonesia. Diterapkannya model tersebut diharapkan keterampilan berbicara peserta didik kelas X IPA-1 MAN Sidoarjo mengalami peningkatan.

\section{Siklus 1}

Hasil pengamatan proses pembelajaran pada siklus 1 dapat dilihat dalam tabel berikut ini.

Tabel persentase hasil pengamatan proses belajar siklus 1

\begin{tabular}{|c|c|c|}
\hline Pertemuan & Hasil & Persentase (\%) \\
\hline Pertama & 1308 & $86,05 \%$ \\
\hline Kedua & 1401 & $92,17 \%$ \\
\hline
\end{tabular}

Hasil pengamatan aktivitas peserta didik pada pertemuan kedua pada tabel tersebut menunjukkan bahwa terjadi peningkatan yang 
positif terhadap pembelajaran yang berlangsung. Hal tersebut dapat dilihat dari kenaikan persentase dari $86,05 \%$ pada pertemuan pertama dan meningkat menjadi $92,17 \%$ pada siklus kedua.

Hasil tes keterampilan berbicara siklus 1

\begin{tabular}{|c|l|c|c|}
\hline No. & \multicolumn{1}{|c|}{$\begin{array}{c}\text { Aspek yang } \\
\text { diamati }\end{array}$} & Nilai & Persentase \\
\hline 1. & Nilai tertinggi & 90 & - \\
\hline 2. & Nilai terendah & 51 & - \\
\hline 3. & $\begin{array}{l}\text { Peserta didik } \\
\text { yang tuntas }\end{array}$ & 16 & $42,10 \%$ \\
\hline 4. & $\begin{array}{l}\text { Peserta didik } \\
\text { yang belum } \\
\text { tuntas }\end{array}$ & 22 & $57,90 \%$ \\
\hline
\end{tabular}

Berdasarkan tabel di atas, nilai keterampilan berbicara peserta didik yang tertinggi 90 dan nilai yang terendah 51, sedangkan peserta didik yang tuntas berjumlah 16 orang jika di persentasekan menjadi $42,10 \%$ dan peserta didik yang belum tuntas berjumlah 22 orang jika di persentasekan menjadi $57,90 \%$.

Berikut ini disajikan tabel untuk mengetahui secara jelas perbandingan skor keterampilan berbicara setiap peserta didik pada pra tindakan dan setelah tindakan pada siklus I.

Tabel Perbandingan hasil belajar pra tindakan dengan siklus 1

\begin{tabular}{|c|c|c|c|c|}
\hline No & Subje & \multicolumn{2}{|c|}{ Skor } & \multirow{2}{*}{ Kenaika } \\
\cline { 3 - 4 } & $\mathbf{k}$ & $\begin{array}{c}\text { Pra } \\
\text { Tindaka } \\
\mathrm{n}\end{array}$ & $\begin{array}{c}\text { Siklu } \\
\text { s } 1\end{array}$ & \\
\hline 1 & $\mathrm{~A}$ & 61 & 70 & 9 \\
\hline 2 & $\mathrm{~B}$ & 47 & 70 & 23 \\
\hline 3 & $\mathrm{C}$ & 48 & 75 & 27 \\
\hline 4 & $\mathrm{D}$ & 28 & 70 & 42 \\
\hline 5 & $\mathrm{E}$ & 52 & 75 & 23 \\
\hline 6 & $\mathrm{~F}$ & 55 & 75 & 20 \\
\hline 7 & $\mathrm{G}$ & 80 & 80 & - \\
\hline
\end{tabular}

\begin{tabular}{|c|c|c|c|c|}
\hline 8 & H & 51 & 80 & 29 \\
\hline 9 & I & 38 & 80 & 4 \\
\hline 10 & J & 65 & 85 & 20 \\
\hline 11 & K & 90 & 90 & - \\
\hline 12 & L & 46 & 80 & 34 \\
\hline 13 & M & 46 & 71 & 25 \\
\hline 14 & N & 42 & 80 & 56 \\
\hline 15 & O & 42 & 75 & 33 \\
\hline 16 & P & 46 & 75 & 29 \\
\hline 17 & Q & 47 & 70 & 23 \\
\hline 18 & R & 47 & 80 & 33 \\
\hline 19 & S & 38 & 80 & 42 \\
\hline 20 & T & 38 & 75 & 37 \\
\hline 21 & U & 56 & 80 & 24 \\
\hline 22 & V & 51 & 80 & 29 \\
\hline 23 & W & 46 & 75 & 29 \\
\hline 24 & X & 47 & 80 & 33 \\
\hline 25 & Y & 80 & 75 & -5 \\
\hline 26 & Z & 28 & 56 & 28 \\
\hline 27 & AA & 51 & 75 & 24 \\
\hline 28 & BB & 46 & 51 & 5 \\
\hline 29 & CC & 37 & 71 & 40 \\
\hline 30 & DD & 33 & 76 & 43 \\
\hline 31 & EE & 51 & 85 & 34 \\
\hline 32 & FF & 75 & 85 & 10 \\
\hline 33 & GG & 80 & 70 & -10 \\
\hline 34 & HH & 37 & 80 & 43 \\
\hline 35 & II & 33 & 71 & 38 \\
\hline 36 & JJ & 33 & 80 & 47 \\
\hline 37 & KK & 42 & 70 & 28 \\
\hline 38 & LL & 42 & 70 & 28 \\
\hline & & & & \\
\hline
\end{tabular}

Bila dilihat dari perbandingan skor keterampilan berbicara peserta didik yang disajikan di atas, terlihat bahwa mengalami peningkatan yang sangat besar pada keterampilan berbicaranya dibandingkan dengan tes yang dilakukan pra tindakan. Dari tabel di atas hanya dua orang peserta didik saja yang mengalami penurunan poin. Jika dalam bentuk grafik perbandingan hasil belajar peserta didik pada pra tindakan dan siklus 1 akan terlihat seperti berikut ini.

Grafik perbandingan hasil belajar pada pra tindakan dengan siklus 1 


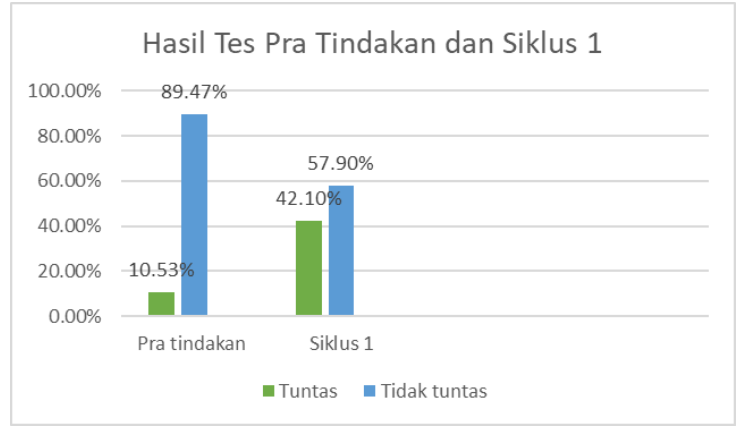

\section{Siklus 2}

Sama halnya dengan siklus1, siklus 2 juga dilakukan sebanyak dua kali pertemuan. Setiap pertemuan dilakukan pengamatan proses pembelajaran dan penilaian hasil tes keterampilan berbicara peserta didik. hasil pengamatan proses pembelajaran setiap pertemuan pada siklus 2 dapat dilihat dalam tabel berikut ini.

Tabel persentase hasil pengamatan proses belajar siklus 1

\begin{tabular}{|c|c|c|}
\hline Pertemuan & Hasil & Persentase (\%) \\
\hline Pertama & 1416 & $93,16 \%$ \\
\hline Kedua & 1441 & $94,80 \%$ \\
\hline
\end{tabular}

Dari data yang disajikan di atas, aktivitas peserta didik telah mengalami peningkatan. Persentase 93,16\% dari persentase maksimal $100 \%$ menunjukkan bahwa sebagian besar peserta didik mengikuti pembelajaran sesuai dengan yang diharapkan. Untuk pertemuan kedua kekurangan-kekurangan pada saat menjalani aktivitas pembelajaran harus diperhatikan dengan jeli dan diperbaiki

Pertemuan kedua menunjukkan peningkatan positif pada aktivitas peserta didik selama pembelajaran berlangsung. Pada kenyataannya di lapangan peserta didik memang lebih kondusif dan aktif memberikan timbal balik positif kepada pengajar.
Peningkatan pada aktivitas peserta didik selama pembelajaran dapat mengindikasikan bahwa peserta didik dapat menerima pembelajaran dengan baik.

Setelah mengamati proses pembelajaran, peneliti menganalisis hasil tes berbicara peserta didik. Berikut hasil tes keterampilan berbicara peserta didik pada pertemuan pertama dan kedua.

Tabel analisis persentase hasil belajar siklus 2

\begin{tabular}{|c|l|c|c|}
\hline No. & \multicolumn{1}{|c|}{$\begin{array}{c}\text { Aspek yang } \\
\text { diamati }\end{array}$} & Nilai & Persentase \\
\hline 1. & Nilai tertinggi & 95 & - \\
\hline 2. & Nilai terendah & 56 & - \\
\hline 3. & $\begin{array}{l}\text { Peserta didik } \\
\text { yang tuntas }\end{array}$ & 31 & $81,58 \%$ \\
\hline 4. & $\begin{array}{l}\text { Peserta didik } \\
\text { yang belum } \\
\text { tuntas }\end{array}$ & 7 & $18,42 \%$ \\
\hline
\end{tabular}

Melalui tabel di atas dapat diketahui bahwa nilai tertinggi yang didapat peserta didik sebesar 95 dan nilai terendah 56. Peserta didik yang tuntas sebanyak 31 orang jika dipersentasekan menjadi $81,58 \%$ dan peserta didik yang belum tuntas masih 7 orang jika dipersentasekan menjadi $18,42 \%$.

Data di atas kemudian dibandingkan dengan data yang diperoleh pada siklus 1 . Hal tersebut dilakukan untuk mengetahui perbandingan hasil dari tindakan pada siklus 1 dan tindakan pada siklus 2 . Berikut adalah tabel perbandingan hasil tes keterampilan berbicara siklus 1 dan hasil tes keterampilan berbicara siklus 2.

Tabel perbandingan hasil belajar siklus 1 dengan siklus 2

\begin{tabular}{|l|c|c|c|c|}
\hline \multirow{2}{*}{ No. } & Subjek & \multicolumn{2}{|c|}{ Skor } & \multirow{2}{*}{ Kenaikan } \\
\cline { 3 - 4 } & $\begin{array}{c}\text { Siklus } \\
1\end{array}$ & $\begin{array}{c}\text { Siklus } \\
2\end{array}$ & \\
\hline
\end{tabular}




\begin{tabular}{|c|c|c|c|c|}
\hline 1 & $\mathrm{~A}$ & 70 & 85 & 15 \\
\hline 2 & B & 70 & 80 & 10 \\
\hline 3 & C & 75 & 75 & - \\
\hline 4 & D & 70 & 85 & 15 \\
\hline 5 & $E$ & 75 & 75 & - \\
\hline 6 & $\mathrm{~F}$ & 75 & 75 & - \\
\hline 7 & $\mathrm{G}$ & 80 & 90 & 10 \\
\hline 8 & $\mathrm{H}$ & 80 & 85 & 5 \\
\hline 9 & I & 80 & 85 & 5 \\
\hline 10 & $\mathrm{~J}$ & 85 & 85 & - \\
\hline 11 & $\mathrm{~K}$ & 90 & 95 & 5 \\
\hline 12 & $\mathrm{~L}$ & 80 & 80 & - \\
\hline 13 & $M$ & 71 & 80 & 10 \\
\hline 14 & $\mathrm{~N}$ & 80 & 85 & 5 \\
\hline 15 & $\mathrm{O}$ & 75 & 90 & 15 \\
\hline 16 & $\mathrm{P}$ & 75 & 75 & - \\
\hline 17 & $Q$ & 70 & 85 & 5 \\
\hline 18 & $\mathrm{R}$ & 80 & 80 & - \\
\hline 19 & $S$ & 80 & 80 & - \\
\hline 20 & $\mathrm{~T}$ & 75 & 80 & 5 \\
\hline 21 & $\mathrm{U}$ & 80 & 85 & 5 \\
\hline 22 & $\mathrm{~V}$ & 80 & 80 & - \\
\hline 23 & $\mathrm{~W}$ & 75 & 85 & 5 \\
\hline 24 & $X$ & 80 & 80 & - \\
\hline 25 & $\mathrm{Y}$ & 75 & 85 & 10 \\
\hline 26 & $\mathrm{Z}$ & 56 & 56 & - \\
\hline 27 & $\mathrm{AA}$ & 75 & 75 & - \\
\hline 28 & $\mathrm{BB}$ & 51 & 80 & 29 \\
\hline 29 & $\mathrm{CC}$ & 71 & 81 & 10 \\
\hline 30 & $\mathrm{DD}$ & 76 & 76 & - \\
\hline 31 & $\mathrm{EE}$ & 85 & 85 & - \\
\hline 32 & FF & 85 & 85 & - \\
\hline 33 & GG & 70 & 85 & 15 \\
\hline 34 & $\mathrm{HH}$ & 80 & 80 & - \\
\hline 35 & II & 71 & 71 & - \\
\hline 36 & JJ & 80 & 80 & - \\
\hline 37 & KK & 70 & 80 & 10 \\
\hline 38 & $\mathrm{LL}$ & 70 & 75 & 5 \\
\hline
\end{tabular}

Melalui perbandingan skor keterampilan berbicara peserta didik dari pra tindakan, siklis 1, sampai siklus 2 mengalami peningkatan yang cukup besar. Berdasarkan hasil ketiga tindakan tersebut, peneliti dan pendidik yang bertindak sebagai kolaborator menganalisis hasil ketiga data. Jika dalam bentuk grafik perbandingan hasil belajar peserta didik pada pra tindakan, siklus 1 , dan siklus 2 akan terlihat seperti berikut ini.
Perbandingan hasil belajar tes pra tindakan, siklus 1, dan siklus 2

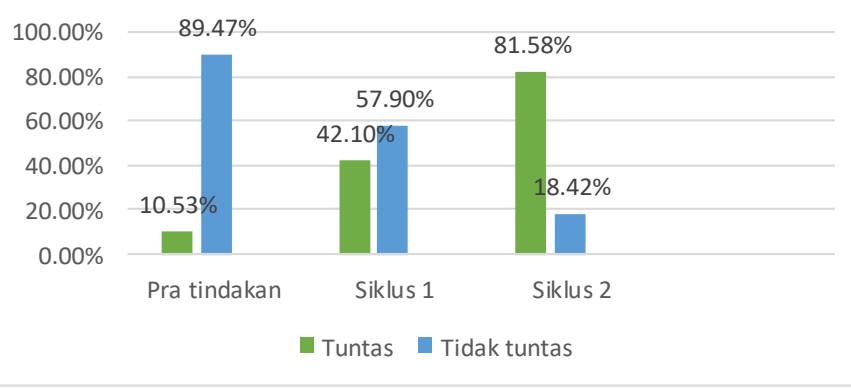

Jika dilihat dari hasil penilaian pada pra tindakan, siklus 1, dan siklus 2 maka didapatkan hasil bahwa peserta didik mengalami peningkatan positif pada setiap siklus yang dilaksanakan. Peningkatan yang terjadi pada setiap siklus ini membuktikan bahwa telah terjadi peningkatan keterampilan berbicara pada peserta didik kelas X IPA-1 MAN Sidoarjo. Pada pra tindakan, skor rata-rata dari seluruh peserta didik adalah 49,34\%, kemudian pada siklus 1 terjadi peningkatan rata-rata skor menjadi $75,68 \%$, dan pada siklus 2 skor meningkat lagi menjadi $80,90 \%$. Berdasarkan peningkatan tersebut peneliti dan pendidik yang bertindak sebagai kolaborator memutuskan untuk menghentikan tindakan pada siklus 2 .

\section{PEMBAHASAN}

Keterampilan berbicara dalam situasi formal dengan menggunakan bahasa Indonesia yang baik dan benar memerlukan latihan dan bimbingan yang intensif. Maka dari itu penelitian ini memfokuskan pembelajaran yang melibatkan seluruh peserta didik dalam proses pembelajaran dengan penerapan model role playing berbasis konstruktivisme. Model pembelajaran role playing merupakan 
model pembelajaran yang bisa langsung diterapkan karena model pembelajaran ini tidak memerlukan pengaturan kelas khusus oleh karena itu, setiap peserta didik dapat berdiskusi dengan teman sebangku atau teman terdekatnya. Setiap pembelajaran yang dilakukan harus menerapkan langkah-langkah model pembelajaran role playing berbasis konstruktivisme.

Keterampilan berbicara peserta didik sebelum tindakan diukur dengan memberikan tes berbicara dengan topik yang sama satu persatu tes tersebut didamakan tes pra tindakan. Tes ini dilakukan untuk melihat kemampuan berbicara peserta didik sebelum diberikan tindakan. Hasil dari tes pra tindakan tersebut menunjukkan bahwa keterampilan berbicara peserta didik masih di bawah nilai ketuntasan minimal dengan skor rata-rata 49,34\%.

Tindakan pada siklus 1 dilakukan dua kali pertemuan pembelajaran. Pada pembelajaran siklus 1 dilakukan tes untuk mengetahui hasil tindakan. Hasil tes pada siklus I adalah 75,68\%. Angka ini menunjukkan bahwa telah terjadi peningkatan pada siklus I dari pra tindakan yang dilakukan sebelumnya. Peningkatan positif ini dilihat dari meningkatnya nilai ratarata seluruh peserta didik pada kelas $X$ IPA-1 MAN Sidoarjo. Pada akhirnya memang terjadi peningkatan positif pada tindakan siklus 1 , namun perlu diperhatikan bahwa skor ratarata yang didapat peserta didik masih menunjukkan skor di bawah ketuntasan minimal 79.

Siklus I yang telah berjalan dan menunjukkan suatu hasil tersebut dievaluasi melalui kegiatan refleksi oleh peneliti dan pendidik. Hasil refleksi yang dilakukan adalah kurang efektifnya strategi pembelajaran yang menyebabkan kurang percaya diri pada peserta didik.

Dari hasil refleksi yang telah ditemukan tersebut, peneliti bersama pendidik mencari solusi untuk memperbaiki proses pembelajaran pada siklus selanjutnya. Solusi yang didapatkan adalah dengan mengganti strategi pembelajaran yaitu strategi cooperative learning. Strategi pembelajaran ini adalah strategi belajar secara berkelompok. Pengubahan strategi ini bertujuan agar peserta didik bisa bebas berekspresi di depan kelas.

Tindakan yang dilakukan pada siklus 2 merupakan hasil refleksi yang dilakukan pada siklus 1. Pada siklus ini langkah-langkah dalam pembelajaran siklus 2 hampir sama dengan siklus 1 yang berbeda hanya pada strategi pembelajaran yang semula secara individu, menjadi berkelompok.

Sama halnya siklus 1 , siklus 2 ini berjalan dengan dua kali pertemuan pembelajaran. Pada kegiatan inti diawali dengan pemberian tes untuk melihat sejauh mana pemahaman peserta didik pada materi yang dibahas bersama selama dua pertemuan ini dan untuk melihat tingkat keterampilan berbicara peserta didik secara keseluruhan. Hasil yang didapat dari tes berbicara siklus 2 adalah skor rata-rata peserta didik yang mencapai $80,90 \%$. Skor rata-rata ini menunjukkan peningkatan dari skor siklus 1 ke siklus 2 . Total kenaikan dari siklus 1 ke siklus 2 yaitu 5,22\%.

Berdasarkan hasil yang telah dicapai, peneliti dan pendidik menyimpulkan bahwa penerapan model pembelajaran role playing berbasis konstruktivisme pada peserta didik kelas X IPA-1 MAN Sidoarjo dikatakan berhasil. 


\section{SIMPULAN DAN SARAN}

Berdasarkan hasil penelitian dan pembahasan dapat disimpulkan bahwa melalui model pembelajaran role laying berbasis konstruktivisme dapat meningkatkan keterampilan berbicara peserta didik kelas X IPA-1 MAN Sidoarjo. Hal tersebut dapat dilihat dari meningkatnya proses pembelajaran dari siklus 1 ke siklus 2 . Pada siklus 1 proses pembelajaran menunjukkan persentase $92,17 \%$, kemudian meningkat menjadi $94,80 \%$ pada siklus 2.

Dari siklus 1 ke siklus 2 juga terjadi peningkatan pada skor ratarata peserta didik dan persentase jumlah peserta didik yang tuntas. Skor rata-rata peserta didik pada siklus 2 naik menjadi 80,90\%. Skor rata-rata tersebut sudah berada di atas nilai KKM yang telah ditentukan sebelumnya. Persentase peserta didik yang mendapatkan nilai sama dengan atau di atas KKM juga sudah tinggi yaitu $81,58 \% \%$. Peningkatan tersebut menunjukkan bahwa penerapan model pembelajaran role playing berbasis konstruktivisme dapat meningkatkan keterampilan berbicara peserta didik kelas X IPA-1 MAN Sidoarjo.

Berdasarkan kesimpulan di atas, dapat dikemukakan saran sebagai berikut. Pendidik sebaiknya menerapkan model pembelajaran role playing berbasis konstruktivisme pada pembelajaran keterampilan berbicara dalam mata elajaran bahasa Indonesia di kelas $X$ dengan pembentukan kelompok kecil atau berpasangan secara acak agar lebih efektif, dan mengontrol proses pembangunan ide peserta didik selama penyampaian pendapat, serta mengontrol proses diskusi agar dalam diskusi tersebut peserta didik dapat berlatih dan memberikan pendapat dengan baik dan optimal.

Peserta didik sebaiknya lebih banyak dilatih berbicara di depan kelas dengan memerhatikan kriteria keterampilan berbicara agar peserta didik terlatih untuk berbicara dengan baik dan benar. Selain itu, berbicara di depan kelas jika dilatih terusmenerus juga dapat meningkat rasa percaya diri yang tinggi apalagi jika dilakukan secara berpasangan atau berkelompok.

\section{DAFTAR PUSTAKA}

Amalia, Dita Rusdia. 2016. Peningkatan Keterampilan Berbicara melalui Model Pembelajaran Kooperatif Tipe Cooperative Script pada Peserta didik Kelas V SDN Karangmojo Bantul.

http://eprints.uny.ac.id/cgi/use rs/login?target $=\mathrm{http} \% 3 \mathrm{~A} \% 2 \mathrm{~F}$ \%2Feprints.uny.ac.id\%2F444 91\%2F1\%2FDita\%2520Rusdi a\%2520Amalia.pdf, diunduh 19 Agustus 2018 pukul 14:21.

Daryanto. 2011. Penelitian Tindakan

Kelas dan Penelitian Tindakan Sekolah.

Yogyakarta: Gava Media.

Ghazali, Syukur. 2010. Pembelajaran

Keterampilan Berbahasa

dengan Pendekatan

Komunikatif-Interaktif.

Bandung: Refika Aditama.

Hanifah, N. 2014. Memahami Penelitian Tindakan Kelas. Bandung: UPI PRESS

Huda, Miftahul. 2014. Cooperatif Learning-Metode, Teknik, dan Model Penerapan. Yogyakarta: Pustaka Pelajar.

Huda, Miftachul. 2018. Model-Model Pengajaran dan Pembelajaran: isu-isu metodis 
dan paradigmatis.

Yogyakarta: Pustaka Pelajar.

Ibrahim, Nurdin dan Darlan Sidik. 2013. Prinsip-prinsip Desain Pembelajaran disesuaikan dengan Kurikulum 2013. Jakarta: Kencana.

Nurhasanah, Ismawati Alidha dkk. 2016. "Penerapan Metode Role Playing untuk Meningkatkan Hasil Belajar Peserta didik pada Materi Hubungan Mahluk Hidup dengan Lingkungannya". Dalam Jurnal Pena Ilmiah, Vol. 1, No 1.

Mulyasa, E. 2014. Pengembangan dan Implementasi Kurikulum 2013. Jakarta: Rosda.

Putra, Eko Arista. 2014. Meningkatkan Kemampuan Berbicara Pengalaman Lucu Peserta didik Kelas X-4 SMA Antartika Sidoarjo Tahun
Pembelajaran 2013/2014 melalui Pembelajaran Kooperatif Tipe Think-PairShare. Skripsi. Universitas PGRI Adi Buana Surabaya. Saddhono, Khundaru dan Y. Slamet. 2014. Pembelajaran Keterampilan Berbahasa Indonesia. Yogyakarta: Graha Ilmu.

Sugiyono. 2016. Metode Penelitian Pendidikan. Bandung: Alfabet.

Suprapto, Hady. 2017. Metodologi Penelitian untuk Karya Ilmiah. Yogyakarta: Gosyen Publishing.

Tarigan, Henry Guntur. 2013. Berbicara sebagai Suatu Keterampilan Berbahasa. Bandung: CV. Angkasa. 